\title{
Cardiac natriuretic peptides and obesity: perspectives from an endocrinologist and a cardiologist
}

\author{
Hugo R Ramos*, Andreas L Birkenfeld ${ }^{1,2, *}$ and Adolfo J de Bold ${ }^{\mathbf{3}}$ \\ Department of Internal Medicine, Faculty of Medicine, Hospital de Urgencias, National University of Córdoba, \\ X5000 Córdoba, Argentina \\ ${ }^{1}$ Section of Metabolic Vascular Medicine, Medical Clinic III and Paul Langerhans Institute Dresden (PLID), \\ Dresden University School of Medicine, 01307 Dresden, Germany \\ ${ }^{2}$ Division of Diabetes and Nutritional Sciences, King's College London, Rayne Institute, London, SE5 9NU, UK \\ ${ }^{3}$ Cardiovascular Endocrinology Laboratory, University of Ottawa Heart Institute, Ottawa, Ontario, Canada \\ *(H R Ramos and A L Birkenfeld contributed equally to this work)
}

\begin{abstract}
Since their discovery in 1981, the cardiac natriuretic peptides (cNP) atrial natriuretic peptide (also referred to as atrial natriuretic factor) and brain natriuretic peptide have been well characterised in terms of their renal and cardiovascular actions. In addition, it has been shown that CNP plasma levels are strong predictors of cardiovascular events and mortality in populations with no apparent heart disease as well as in patients with established cardiac pathology. cNP secretion from the heart is increased by humoral and mechanical stimuli. The clinical significance of cNP plasma levels has been shown to differ in obese and non-obese subjects. Recent lines of evidence suggest important metabolic effects of the cNP system, which has been shown to activate lipolysis, enhance lipid oxidation and mitochondrial respiration. Clinically, these properties lead to browning of white adipose tissue and to increased muscular oxidative capacity. In human association studies in patients without heart disease higher cNP concentrations were observed in lean, insulin-sensitive subjects. Highly elevated cNP levels are generally observed in patients with systolic heart failure or high blood pressure, while obese and type- 2 diabetics display reduced cNP levels. Together, these observations suggest that the CNP system plays a role in the pathophysiology of metabolic vascular disease. Understanding this role should help define novel principles in the treatment of cardiometabolic disease.
\end{abstract}

Key Words
- natriuretic peptides
- ANP
- ANF
- BNP
- NT-proBNP
- heart disease
- obesity

\section{Introduction}

Two male patients with type 2 diabetes (T2D) and coronary heart disease had plasma levels of brain natriuretic peptide (BNP) and N-terminal probrain natriuretic peptide (NT-proBNP) measured as part of routine evaluation. Both were hypertensive with hyper cholesterolemia and hypertriglyceridemia. Their glomerular filtration rate was normal ( $>75 \mathrm{ml} / \mathrm{min}$ per $1.73 \mathrm{~m}^{2}$ ), HbA1c was $<7 \%$ with metformin, and C-reactive protein (CRP) was $<1 \mathrm{mg} / \mathrm{dl}$ in both. Patient A was 71 years old and had suffered an anterior myocardial infarction three years ago with http://www.endocrineconnections.org DOI: 10.1530/EC-15-0018
(C) 2015 The authors Published by Bioscientifica Ltd
This work is licensed under a Creative Commons Attribution-NonCommercial 4.0 International License. 
ST-segment elevation, which was initially treated with fibrinolytics and $24 \mathrm{~h}$ later using percutaneous coronary intervention with a drug eluting stent on the anterior coronary descending artery. He presented with a $>70 \%$ stenosis on a diagonal artery, which was not treated and showed no significant stenosis in the remaining coronary arteries. His BMI was $34.8 \mathrm{~kg} / \mathrm{m}^{2}$, waist circumference $116 \mathrm{~cm}$ and was stable without chest pain in NYHA class I. The echocardiogram showed apical and lateral hypokinesia with left ventricular ejection fraction (LVEF) of 58\%. Plasma BNP and NT-proBNP were 72 and $100 \mathrm{pg} / \mathrm{ml}$, respectively (reference values for age and sex: BNP median $28 \mathrm{pg} / \mathrm{ml}$ (percentile 25-75th, 10-58 pg/ml); NT-proBNP median $45 \mathrm{pg} / \mathrm{ml}$ (percentile 5-95th, 14-140 pg/ml)).

Patient B, 58 years of age, had suffered a nonST-elevation myocardial infarction two years earlier, and had received standard treatment. No coronary angiography was done due to his weight (144 kg). His BMI was $44.3 \mathrm{~kg} / \mathrm{m}^{2}$ and his waist circumference $137 \mathrm{~cm}$. He was in stable condition without chest pain, in NYHA class II. The echocardiogram showed mild hypokinesia of the basal segment of the inferior wall and mild dilation of left ventricle with eccentric hypertrophy. LVEF was $66 \%$ and plasma BNP and NT-proBNP were 10 and $<20 \mathrm{pg} / \mathrm{ml}$, respectively (reference values for age and sex: BNP median $31 \mathrm{pg} / \mathrm{ml}$, percentile 25-75th, 14-49 pg/ml; NT-proBNP median $25 \mathrm{pg} / \mathrm{ml}$, percentile 5-95th, 5-88 pg/ml).

These findings posed the question as to why it is that in some patients the plasma levels of cardiac natriuretic peptides (cNP) are unexpectedly low, and what is their value in the prognosis for these patients?

\section{The cardiologist's perspective}

The cNP act as a basic functional link between cardiovascular system homeostasis, inflammation and certain metabolic functions (Fig. 1).

Increased secretion of cNP is a result of both mechanical and neurohumoral stimuli $(1,2)$. The main mechanical stimulus for the secretion of cNP is the increased pressure in the cardiac chambers leading to stretching of the myocardial fibers. This phenomenon is referred to as stretch-secretion coupling (3). Neurohumoral stimuli include endothelin-1, angiotensin II, adrenergic agonists and various cytokines (4). Increased left ventricular end-diastolic wall stress and left ventricular end-systolic wall stress correlate with an increase in plasma cNP in heart failure $(5,6)$. However, studies on cardiac transplant patients have shown that plasma cNP levels remain high even after intra-cardiac pressures normalize following transplantation (7). During an acute cardiac allograft rejection episode, BNP - but not atrial natriuretic peptide (ANP) - plasma levels increase significantly above pre-rejection values independently of the surgical technique used (8). Plasma BNP levels during acute rejection episodes do not correlate with hemodynamic variables but correlate with the levels of regulated on activation, normal $\mathrm{T}$ expressed and secreted, insulin growth factor binding protein-1 and neutrophil activating protein-2 (4). In non-rejecting transplanted patients, despite the normalization of endothelin-1 plasma levels and diastolic and systolic functions, BNP remains high by comparison with control subjects (9).

Measuring cNP is useful as a diagnostic and prognostic tool $(10,11,12)$. High plasma levels of cNP (e.g. BNP $>63 \mathrm{pg} / \mathrm{ml}$ or NT-proBNP $>206 \mathrm{pg} / \mathrm{ml}$ ) can quite precisely predict which patients are at risk for events such as hospitalization due to systolic heart failure or cardiovascular death $(13,14,15,16,17,18)$. Obese patients may have strikingly low levels of plasma cNP $(19,20,21,22)$ due to multiple mechanisms that might include increased neprilysin-neutral endopeptidase activity resulting in increased degradation of circulating cNP and increased adipose tissue expression of the NP clearance receptor $\mathrm{C}$ (NPRC). It has been proposed that suppression of proBNP ${ }_{1-108}$ prohormone processing due to O-glycosylation at its cleavage site where furine or corin convertases act, prevents the formation of $\mathrm{BNP}_{77-108}$ (functionally active) and NT-proBNP ${ }_{1-76}$ (inactive) fragments, an event that is purportedly more frequent in diabetics and in insulin-resistant states $(23,24,25)$. In heart failure patients, the precursor pro-hormone proBNP ${ }_{1-108}$ is found circulating at lower than normal levels $(26,27)$.

Recently, the PARADIGM-HF trial showed that angiotensin receptor-neprilysin inhibition using the compound LCZ-696, $200 \mathrm{mg}$ twice daily, compared with enalapril at $10 \mathrm{mg}$ twice daily significantly reduced the risk of cardiovascular death and hospitalization in patients with heart failure with an LVEF $\leq 40 \%$. However, death rates from cardiovascular causes were similar among diabetics compared with non-diabetics (28). Although this interesting finding could be an accidental one, other heart failure trials found that the benefit of this therapy in diabetics seems to be less than that in non-diabetics (29, $30,31)$. This finding merits further research, since diabetics comprise $25-35 \%$ of the subjects in most studies $(29,30,31,32)$.

The obese are differentiated from the 'metabolically healthy obese' by an 'unhealthy metabolic' profile (33). 


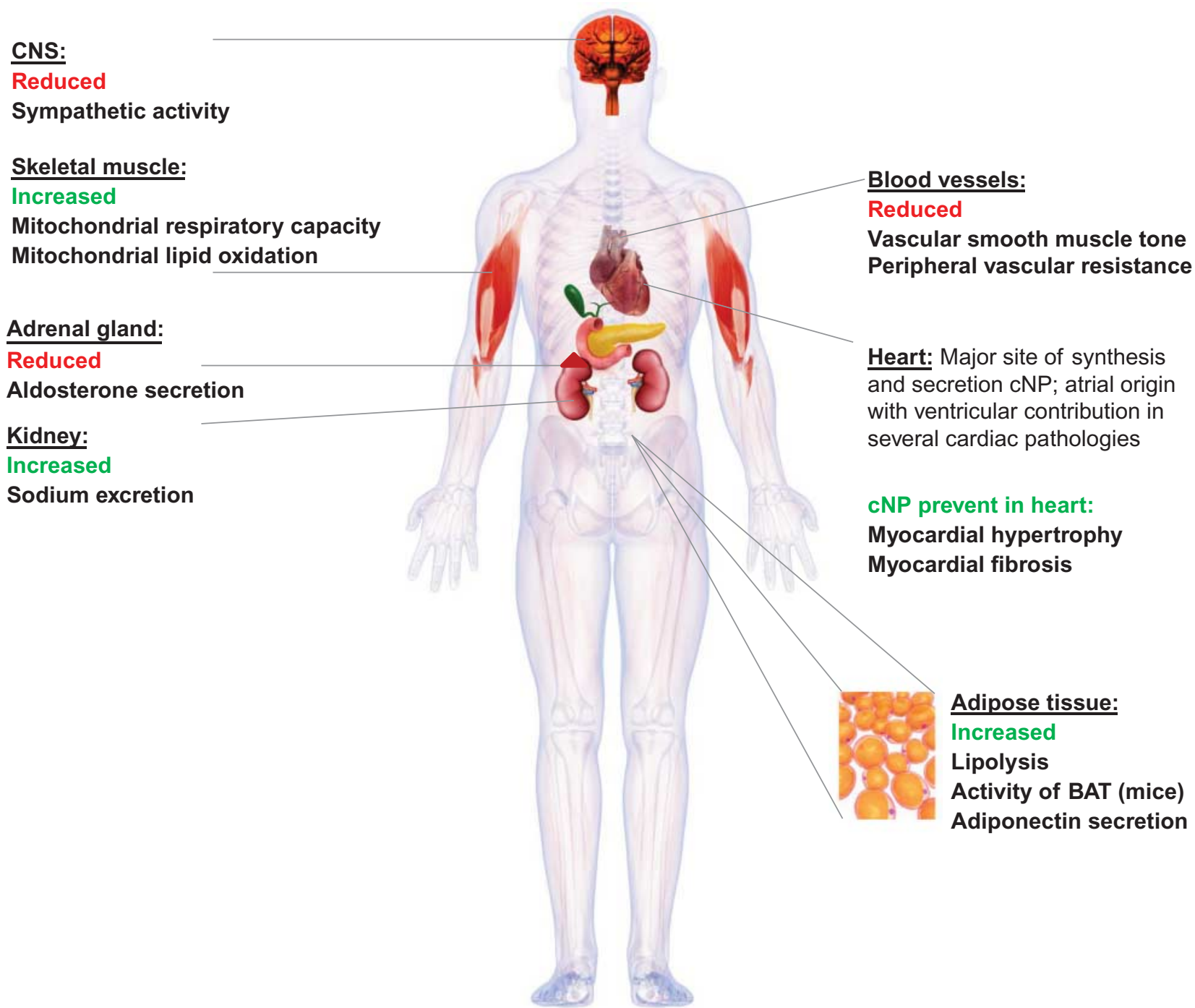

Figure 1

Main biological targets and effects of the cardiac natriuretic peptides ANP and BNP.

The latter is defined by increased waist circumference $(>94 \mathrm{~cm}$ in men and $>80 \mathrm{~cm}$ in women) or BMI $\geq 30 \mathrm{~kg} / \mathrm{m}^{2}$ accompanied by two or more of the following: hypertriglyceridemia $(1.7 \mathrm{mmol} / \mathrm{l})$, low HDL cholesterol $(<1.03 \mathrm{mmol} / \mathrm{l}$ in men and $<1.29 \mathrm{mmol} / \mathrm{l}$ in women), hyperglycemia ( $>11.1 \mathrm{mmol} / \mathrm{l}$ or a diagnosis of diabetes), hypertension $(\geq 130 / 85 \mathrm{mmHg}$ ) or medication for high blood pressure $(34,35)$. In a 12-year follow-up of 61299 subjects free from cardiovascular disease at baseline Mørkedal et al. (36) observed that systolic heart failure development was similar among 'metabolically healthy' compared to 'non-metabolically healthy' obese subjects, meaning that obesity per se creates a higher risk for developing systolic heart failure, especially if it is long-lasting and severe (BMI $>40 \mathrm{~kg} / \mathrm{m}^{2}$ ). In contrast, the risk of acute myocardial infarction in 'obese metabolically unhealthy' subjects was significantly higher compared to 'obese metabolically healthy subjects'(35). Recently, it was reported that subjects with high plasma levels of NT-proBNP are at a greater risk of developing systolic heart failure whether they are obese or non-obese. However, unlike the non-obese who show a direct linear relationship between levels of NT-proBNP and systolic heart failure, the obese show a U-shaped relationship; i.e. those who have the lowest plasma levels are at just as much risk of developing systolic heart failure as those with the highest plasma levels (37). In contrast, the pathological weight loss caused by anorexia nervosa seems to be http://www.endocrineconnections.org DOI: 10.1530/EC-15-0018
(C) 2015 The authors Published by Bioscientifica Ltd
This work is licensed under a Creative Commons Attribution-NonCommercial 4.0 International License. 
related to high plasma levels of ANP (38). In severe obesity, bariatric surgery reduces the BMI and improves control of diabetes but it is not yet known if it reduces the risk of cardiovascular events $(39,40,41,42,43,44,45,46)$. In patients with severe obesity (BMI $>40 \mathrm{~kg} / \mathrm{m}^{2}$ ) before gastric bypass surgery, the median level of NT-proBNP was $54 \mathrm{pg} / \mathrm{ml}$ increasing by $125 \%$ after 1 year with no apparent relation to weight loss or glucometabolic parameters. It was speculated that an improvement in secretory cardiac function following surgery was responsible for the increase in circulating NT-proBNP (46).

Myocardial ischemia and cardiomyocyte stretch trigger the immediate release of $\mathrm{cNP}(47,48)$ even when the LVEF is normal $(49,50)$. In a 9.2 year follow-up study of diabetic (about 7\% of the cohort) and non-diabetic patients with chronic stable myocardial ischemia, high plasma levels of NT-proBNP were significantly associated with mortality regardless of left ventricular function (51). Recently, it was shown that in patients with stable coronary heart disease BNP and NT-proBNP were strong predictors of long-term $(6.5 \pm 3.3$ years $)$ cardiovascular events and notably, when NT-proBNP was added to the clinical predictors, it performed better than BNP in risk classification for adverse cardiovascular events (52). Serial measurement data for NT-proBNP in patients with chronic stable angina have shown a wide intra-individual variation. An increase by $>42 \%$ or a decrease by $>30 \%$ relative to baseline values is required to indicate a significant change $(53,54)$. In patients presenting with acute chest pain, cNP plasma levels help the diagnosis and prognosis when used together with a non-diagnostic ECG and a negative troponin. cNP measured in these patients at rest predict future cardiac events at 30 and 180 days and at 1 year $(55,56,57,58)$. If myocardial ischemia is evident during the stress test, an elevation of the plasma levels of NT-proBNP detects ischemia and predicts cardiovascular events (59). Likewise, in non-ST-elevation acute coronary syndromes, cNP add prognostic information to the clinical indicators $(60,61,62,63)$ (Table 1).

In a recent investigation (62), BNP was shown to be an independent predictor of mortality on entering the study. At 1 year of follow-up BNP plasma levels provided added value over the TIMI and GRACE scores. cNP are stronger predictors of mortality than troponin in patients that will eventually develop myocardial infarction. In ST-segment-elevation acute coronary syndromes cNP plasma levels also add prognostic information independently of the $\operatorname{LVEF}(50,64,65)$ and in addition, predict which patients with primary percutaneous coronary intervention (PCI) may be discharged earlier thus saving health resources (66).

It has been shown experimentally that ANP is associated with salt-sensitive high blood pressure (67). In humans it has been shown that plasma ANP and high blood pressure correlate negatively. Alleles associated with the highest levels of NP were also associated with a lower risk of high blood pressure $(68,69)$. In keeping with these findings, another study showed a relative deficiency of cNP at all the different stages of high blood pressure in humans consisting of low levels of proBNP ${ }_{1-108}$ and $\mathrm{ANP}_{\text {99-126. }}$. Low plasma levels of $\mathrm{BNP}_{76-108}$ and NT-proBNP ${ }_{1-76}$ were observed in the first hypertensive stages together with a reduction of NT-ANP ${ }_{1-98}$ in stage I (70).

A possible therapeutic modality to supplement cNP in those cases in which circulating cNP are deemed deficient (like in hypertension or heart failure) is suggested by the development of a recombinant human serum albuminatrial natriuretic factor (ANF) (71) molecule. This compound, when injected into mice increased circulating cGMP and decreased blood pressure demonstrated a halflife of $>80 \mathrm{~min}$, which is considerably longer than the 5-10 min half-life for native ANF $(71,72,73)$.

From the preceding, it may be surmised that elevated cNP levels are strong markers of future cardiovascular events, especially cardiovascular death. On the other hand, cNP plasma levels lower than expected in obese and diabetic patients could be predictive of adverse outcomes.

In summary, the two patients discussed above had similar metabolic profiles, LVEF $>50 \%$ but a different BMI and cNP profile. Patient A was not severely obese and had slight residual myocardial ischemia with BNP and NT-proBNP within low to moderate values expected for systolic heart failure and cardiovascular mortality on follow-up. Patient B suffered from severe obesity, with very low plasma levels of cNP with a prognosis related to his BMI of $>40 \mathrm{~kg} / \mathrm{m}^{2}$ and probably also to a deficit of cNP, placing him in the high-risk category for developing systolic heart failure and eventual cardiovascular death.

\section{The endocrinologist's perspective}

Our patient A has markedly higher BNP and NT-proBNP levels compared to patient $\mathrm{B}$. This can largely be explained by the better ejection fraction of patient $\mathrm{B}$, but there might also be other contributing factors. For example, recent studies suggest an inverse relationship between circulating cNP levels and bodyweight as well as with insulin resistance and T2D $(19,74,75,76,77,78)$ (Table 1$)$. This 
Table 1 Values for cardiac natriuretic peptide plasma levels in heart failure and coronary heart disease.

\begin{tabular}{|c|c|c|c|}
\hline Clinical syndrome & $\begin{array}{l}\text { Natriuretic peptide } \\
(\mathrm{pg} / \mathrm{ml})\end{array}$ & Value & Reference \\
\hline $\begin{array}{l}\text { Acute heart failure } \\
\text { (exclusion cut-off point) }\end{array}$ & BNP & $<100$ & $(11,133)$ \\
\hline & NT-proBNP & $<300$ & \\
\hline $\begin{array}{l}\text { Non-acute presentation of possible heart failure } \\
\text { (exclusion cut-off point) }\end{array}$ & BNP & $<35$ & (11) \\
\hline & NT-proBNP & $<125$ & \\
\hline Chronic heart failure (indicators of high risk) & $\begin{array}{l}\text { BNP } \\
\text { NT-proBNP }\end{array}$ & $\begin{array}{l}>125 \\
>1000\end{array}$ & $(134)$ \\
\hline Unstable angina (indicators for non-invasive stress testing) & $\begin{array}{l}\text { BNP } \\
\text { NT-proBNP }\end{array}$ & $\begin{array}{l}<80 \\
<250\end{array}$ & $(135)$ \\
\hline Stable chronic coronary disease (cardiovascular death \%) & NT-proBNP & $\begin{array}{l}\text { Q I < }<18(8) \\
\text { Q II 18-42(10) } \\
\text { Q III 43-102(15) } \\
\text { Q IV >102(28) } \\
\text { Q I <74 (4) } \\
\text { Q II 74-174 (9) } \\
\text { QIII 175-460(17) } \\
\text { Q IV > 460 (30) }\end{array}$ & $(51)$ \\
\hline
\end{tabular}

$\mathrm{Q}$, quartile.

correlation can also be observed in patients with congestive heart failure, despite increased cNP levels, due to cardiac wall stress (79). Several explanations have been proposed. First, increased cNP degradation seems to be one possible cause. cNP are cleared and degraded by neutral endopeptidase neprilysin and natriuretic peptide receptor C (NPRC) $(80,81)$. Natriuretic peptide receptor A (NPRA) and NPRC have been identified in human adipose tissue in abundance, implying that adipose tissue sustains a regulatory function on the NP system $(82,83,84)$. Interestingly, compared to non-obese and normotensive individuals, NPRC is increased in adipose tissue of obese hypertensive patients (85). Insulin has been observed to induce NPRC expression in human adipocytes (84) and monocytes (83), and might, hence, link conditions associated with hyperinsulinemia (e.g. obesity and insulin resistance), to a relative NP deficit. Additionally, neprilysin, the NP degrading endopeptidase, is expressed at increased levels in obesity (86). These data argue for obesity and insulin resistance being conditions in which cNP are degraded at an accelerated pace. Second, very recent experimental data also suggest that myocardial BNP expression is markedly decreased in mice fed a high fat diet (87), an observation that warrants clinical confirmation.

A cNP deficit in patients with components of the metabolic syndrome might be of clinical relevance. First, it might link obesity to arterial hypertension. Obese individuals have a higher prevalence of arterial hypertension compared to lean subjects (88). Although obesity-related arterial hypertension has been intensively studied, not all mechanisms are well understood $(89,90)$. By reduced vasodilatory and sodium-excretion activity, as well as decreased suppression of the renin-angiotensinaldosterone-system (RAAS), a cNP deficit might contribute to obesity related hypertension. Interestingly, in lean subjects, application of a sodium load induces myocardial cNP secretion and stimulates natriuresis $(91,92,93,94)$, a response which is blunted in patients with obesity (95). Together, these data argue that obesity promotes hypertension partly through reduced vascular and renal NP responses as well as through impaired NP-mediated RAAS inhibition. Second, cNP also have beneficial actions on cardiac remodelling in essential hypertension, reducing left ventricular hypertrophy (96). Conversely, conditions with a cNP deficit are associated with cardiac hypertrophy in hypertensive patients. In this regard, hypertensive patients with the metabolic syndrome present with lower ANP and NT-proBNP levels and increased left ventricular mass compared to hypertensive patients without the metabolic syndrome and insulin resistance (97).

Finally, the cNP deficit in patients with the metabolic syndrome might be part of a vicious circle which maintains metabolic disease. cNP have distinct metabolic effects. For instance, cNP exert lipolytic properties mediated by a cGMP-dependent protein kinase G activating pathway. cGMP-activated protein kinase G (GK-I) activates perilipin $\mathrm{A}$ and hormone sensitive lipase

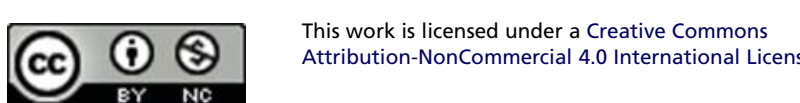


mediated triglyceride hydrolysis (98, 99, 100, 101). Interestingly, these effects seem not to interact with the lipolytic effects of catecholamines $(99,102)$ and the effect seems to be independent of the regulation of insulin (103).

Besides a direct activating effect on lipolysis and lipid oxidation, cNP also control secretion of the insulin sensitizing adipokine adiponectin. In humans, ANP acutely increases systemic levels of total and high molecular weight adiponectin (104). These findings are in line with some observational studies showing positive associations between systemic cNP and adiponectin concentrations, as for example in heart failure patients $(105,106)$. This finding might also explain the 'adiponectin paradox' in patients with congestive heart failure.

cNP also exert other relevant metabolic actions on adipose tissue. Treating a human derived adipose cell line with ANP results in the uncoupling of cellular respiration (107) as well as 'browning' of white adipose tissue. The response seems to be mediated by p38 MAP kinase, which increases uncoupling protein 1 (UCP1) transcription (107). Upon cold exposure, systemic NP concentrations increase and NPRC expression in adipose tissue decreases. Similarly, forced PKG expression in primary adipocytes leads to an increase in UCP1 expression and activates a thermogenic program. Together, these studies suggest that the NP system induces a 'browning' program in adipose tissue (108).

cNP also exert metabolic actions in liver and skeletal muscle. We observed that short term i.v. administration of ANP acutely increases lipid oxidation $(102,109)$ and postprandial energy expenditure in healthy individuals (110). Circulating $\beta$-hydroxybutyrate increases, indicating enhanced hepatic lipid oxidation. Apart from acute effects on lipid oxidation (110), ANP and BNP induce skeletal muscle mitochondrial biogenesis, respiration and lipid oxidation in human cells and in rodents, in vitro and in vivo $(111,112)$. Chronic overexpression of BNP and GK-I each led to increased muscle mitochondrial content, oxidative capacity and lipid oxidation in rodents (111). Enhanced oxidative metabolism is associated with protection from diet induced obesity and insulin resistance (113). Heterozygous NPRA knockout mice are prone to gaining weight and become insulin resistant (111). The mechanism linking NP signalling to mitochondrial biogenesis and lipid oxidation in skeletal muscle includes activation of the co-transcriptional activator peroxisome proliferatoractivated receptor $\gamma$ coactivator (PGC)- $1 \alpha$ and peroxisome proliferator-activated receptor- $\delta$, both of which are important factors of mitochondrial biogenesis in skeletal muscle (111).
In human myotubes, we observed that cNP stimulate PGC-1 $\alpha$, maximal mitochondrial respiratory capacity and lipid oxidation (112). Moreover, NPRA expression positively correlates with PGC- $1 \alpha$ expression in the skeletal muscle of individuals after a chronic physical training program. Similarly, cell culture studies show that cGMP restores glucose and insulin induced mitochondrial dysfunction in cultured C2C12 myotubes (114), nitric oxide signalling via cGMP mediates activation of PGC- $1 \alpha$, and mitochondrial biogenesis in various murine tissues (115).

Hepatic and skeletal muscle lipid content has been associated with insulin resistance (113). In liver and skeletal muscle, insulin resistance develops when bioactive lipid species accumulate, such as intracellular diacylglycerol (113). In obesity and the metabolic syndrome, this lipid accumulation is primarily due to excessive caloric intake that exceeds the capacity of hepatocytes and myocytes to metabolize or export fatty acids, while refining mitochondrial respiration and enhancing lipid oxidation have been proved to improve lipid utilization and insulin sensitivity $(116,117,118)$. So far, there is no evidence that cNP directly interact with the insulin signalling cascade $(109,119)$. It is tempting to speculate that cNP could ameliorate lipid-induced insulin resistance through improvements in hepatic (110) and muscular (112) lipid oxidation. In line with this notion, cNP preserves mitochondrial function and insulin sensitivity in high fat diet mice (111). Cross sectional studies support the hypothesis that cNP protect from the development of obesity and T2D in patients $(78,120$, 121,122). Conversely, data from the Framingham Heart Study and the Malmö Diet and Cancer study show that reduced cNP concentrations correlate with a higher probability of insulin resistance in lean and obese individuals (76). Moreover, in the latter study low cNP concentrations are predictive of new-onset diabetes (123). Together, these data suggest that a cNP deficit, as observed in obese patients with the metabolic syndrome, contributes and aggravates metabolic vascular disease, and thus, prognosis. Further studies are needed to determine how such a deficit can be corrected. Life style interventions as well as pharmacological approaches might be of benefit in this regard $(28,124)$. While physical activity increases cNP levels acutely and augments NPRA expression in skeletal muscle cells (112), physical activity coupled with a low calorie diet seems to increase cNP levels chronically (125); an observation that seems to depend on the amount of weight loss $(126,127)$. Experimental data further suggests that the incretin glucagon like peptide 1 (GLP1) might be of relevance in the regulation of NP secretion. The GLP1

This work is licensed under a Creative Commons Attribution-NonCommercial 4.0 International License. 
receptor agonist liraglutide, which is widely used for the treatment of $\mathrm{T} 2 \mathrm{D}$, has been shown to induce cardiac ANP release in mice, leading to enhanced natriuresis and vasodilatation (128) without inducing congestive heart failure. So far 25 clinical studies failed to demonstrate a similar effect of liraglutide when administered acutely (129) or sub-chronically to patients (130). Chronic liraglutide treatment, accompanied by weight loss, however, seems to increase circulating ANP as well as BNP concentrations in diabetic patients (131). Clearly, future studies need to address the important question how a cNP deficit in obesity and T2D can be reversed most efficiently (132).

\section{Declaration of interest}

The authors declare that there is no conflict of interest that could be perceived as prejudicing the impartiality of this review.

\section{Funding}

This work was supported by a grant from the Secretaría de Ciencia y Tecnología de la Universidad Nacional de Córdoba (grant number 69/08) to H R Ramos, a grant from the German Research Foundation (grant number BI1292/4-2) to A L Birkenfeld and by funds from the University of Ottawa to A J de Bold.

\section{References}

1 Ogawa T \& de Bold AJ. The heart as an endocrine organ. Endocrine Connections 20143 R31-R44. (doi:10.1530/EC-14-0012)

2 Ramos H \& de Bold AJ. Gene expression, processing and secretion of natriuretic peptides: physiologic and diagnostic implications. Heart Failure Clinics 20062 255-268. (doi:10.1016/j.hfc.2006.08.005)

3 Kuroski de Bold ML \& de Bold AJ. Stretch-secretion coupling in atrial cardiocytes. Dissociation between atrial natriuretic factor release and mechanical activity. Hypertension 199118 III-169-III-178. (doi:10.1161/01.HYP.18.5_Suppl.III169)

4 Meirovich YF, Veinot JP, de Bold ML, Haddad H, Davies RA, Masters RG, Hendry PJ \& de Bold AJ. Relationship between natriuretic peptides and inflammation: proteomic evidence obtained during acute cellular cardiac allograft rejection in humans. Journal of Heart and Lung Transplantation 200827 31-37. (doi:10.1016/j.healun.2007. 09.025)

5 Iwanaga Y, Nishi I, Furuichi S, Noguchi T, Sase K, Kihara Y, Goto Y \& Nonogi H. B-type natriuretic peptide strongly reflects diastolic wall stress in patients with chronic heart failure: comparison between systolic and diastolic heart failure. Journal of the American College of Cardiology 200647 742-748. (doi:10.1016/j.jacc.2005.11.030)

6 Maeder MT, Mariani JA \& Kaye DM. Hemodynamic determinants of myocardial B-type natriuretic peptide release: relative contributions of systolic and diastolic wall stress. Hypertension 201056 682-689. (doi:10.1161/HYPERTENSIONAHA.110.156547)

7 Masters RG, Davies RA, Veinot JP, Hendry PJ, Smith SJ \& de Bold AJ. Discoordinate modulation of natriuretic peptides during acute cardiac allograft rejection in humans. Circulation 1999100 287-291. (doi:10.1161/01.CIR.100.3.287)

8 El Gamel A, Yonan NA, Keevil B, Warbuton R, Kakadellis J, Woodcock A, Campbell CS, Rahman AN \& Deiraniya AK. Significance of raised natriuretic peptides after bicaval and standard cardiac transplantation. Annals of Thoracic Surgery 199763 1095-1100. (doi:10.1016/S0003-4975(97)00168-9)

9 Talha S, Charloux A, Enache I, Piquard F \& Geny B. Mechanisms involved in increased plasma brain natriuretic peptide after heart transplantation. Cardiovascular Research 201189 273-281. (doi:10.1093/cvr/cvq331)

10 Gimelli A, Lancellotti P, Badano LP, Lombardi M, Gerber B, Plein S, Neglia D, Edvardsen T, Kitsiou A, Scholte AJ et al. Non-invasive cardiac imaging evaluation of patients with chronic systolic heart failure: a report from the European Association of Cardiovascular Imaging (EACVI). European Heart Journal 201435 3417-3425. (doi:10.1093/ eurheartj/ehu433)

11 McMurray JJ, Adamopoulos S, Anker SD, Auricchio A, Bohm M, Dickstein K, Falk V, Filippatos G, Fonseca C, Gomez-Sanchez MA et al. ESC guidelines for the diagnosis and treatment of acute and chronic heart failure : The Task Force for the Diagnosis and Treatment of Acute and Chronic Heart Failure 2012 of the European Society of Cardiology. Developed in collaboration with the Heart Failure Association (HFA) of the ESC. European Journal of Heart Failure 201214 803-869. (doi:10.1093/eurjhf/hfs033)

12 Yancy CW, Jessup M, Bozkurt B, Butler J, Casey DE Jr, Drazner MH, Fonarow GC, Geraci SA, Horwich T, Januzzi JL et al. ACCF/AHA guideline for the management of heart failure: a report of the American College of Cardiology Foundation/American Heart Association Task Force on practice guidelines. Circulation 2013128 e240-e327. (doi:10.1161/CIR.0b013e31829e8807)

13 McKie PM, Rodeheffer RJ, Cataliotti A, Martin FL, Urban LH, Mahoney DW, Jacobsen SJ, Redfield MM \& Burnett JC Jr. Aminoterminal pro-B-type natriuretic peptide and B-type natriuretic peptide: biomarkers for mortality in a large community-based cohort free of heart failure. Hypertension 200647 874-880. (doi:10.1161/01.HYP. $0000216794.24161 .8 \mathrm{c})$

14 Galasko GI, Lahiri A, Barnes SC, Collinson P \& Senior R. What is the normal range for N-terminal pro-brain natriuretic peptide? European Heart Journal 200526 2269-2276. (doi:10.1093/eurheartj/ehi410)

15 Wang TJ, Larson MG, Levy D, Benjamin EJ, Leip EP, Omland T, Wolf PA \& Vasan RS. Plasma natriuretic peptide levels and the risk of cardiovascular events and death. New England Journal of Medicine 2004 350 655-663. (doi:10.1056/NEJMoa031994)

16 Zaphiriou A, Robb S, Murray-Thomas T, Mendez G, Fox K, McDonagh T, Hardman SM, Dargie HJ \& Cowie MR. The diagnostic accuracy of plasma BNP and NTproBNP in patients referred from primary care with suspected heart failure: results of the UK natriuretic peptide study. European Journal of Heart Failure 20057 537-541. (doi:10.1016/j.ejheart.2005.01.022)

17 Mogelvang R, Goetze JP, Pedersen SA, Olsen NT, Marott JL, Schnohr P, Sogaard P \& Jensen JS. Preclinical systolic and diastolic dysfunction assessed by tissue Doppler imaging is associated with elevated plasma pro-B-type natriuretic peptide concentrations. Journal of Cardiac Failure 200915 489-495. (doi:10.1016/j.cardfail.2009.01.005)

18 Mogelvang R, Sogaard P, Pedersen SA, Olsen NT, Schnohr P \& Jensen JS. Tissue Doppler echocardiography in persons with hypertension, diabetes, or ischaemic heart disease: the Copenhagen City Heart Study. European Heart Journal 200930 731-739. (doi:10.1093/ eurheartj/ehn596)

19 Wang TJ, Larson MG, Levy D, Benjamin EJ, Leip EP, Wilson PWF \& Vasan RS. Impact of obesity on plasma natriuretic peptide levels. Circulation 2004109 594-600. (doi:10.1161/01.CIR.0000112582. 16683.EA)

20 McCord J, Mundy BJ, Hudson MP, Maisel AS, Hollander JE, Abraham WT, Steg PG, Omland T, Knudsen CW, Sandberg KR et al. Relationship between obesity and B-type natriuretic peptide levels. Archives of Internal Medicine 2004164 2247-2252. (doi:10.1001/ archinte.164.20.2247)

21 Daniels LB, Clopton P, Bhalla V, Krishnaswamy P, Nowak RM, McCord J, Hollander JE, Duc P, Omland T, Storrow AB et al. How 
obesity affects the cut-points for B-type natriuretic peptide in the diagnosis of acute heart failure. Results from the Breathing Not Properly Multinational Study. American Heart Journal 2006151 999-1005. (doi:10.1001/archinte.164.20.2247)

22 Nakane T, Kawai M, Komukai K, Kayama Y, Matsuo S, Nagoshi T, Minai K, Date T, Ogawa T, Yagi H et al. Contribution of extracardiac factors to the inconsistency between plasma B-type natriuretic peptide levels and the severity of pulmonary congestion on chest X-rays in the diagnosis of heart failure. Internal Medicine 201251 239-248. (doi:10.2169/internalmedicine.51.6206)

23 Semenov AG, Postnikov AB, Tamm NN, Seferian KR, Karpova NS, Bloshchitsyna MN, Koshkina EV, Krasnoselsky MI, Serebryanaya DV \& Katrukha AG. Processing of pro-brain natriuretic peptide Is suppressed by O-glycosylation in the region close to the cleavage site. Clinical Chemistry 20093 489-498. (doi:10.1373/clinchem.2008.113373)

24 Tonne JM, Campbell JM, Cataliotti A, Ohmine S, Thatava T, Sakuma T, Macheret F, Huntley BK, Burnett JC Jr \& Ikeda Y. Secretion of glycosylated pro-B-type natriuretic peptide from normal cardiomyocytes. Clinical Chemistry 201157 864-873. (doi:10.1373/clinchem. 2010.157438)

25 Vodovar N, Seronde MF, Laribi S, Gayat E, Lassus J, Boukef R, Nouira S, Manivet P, Samuel JL, Logeart D et al. Post-translational modifications enhance NT-proBNP and BNP production in acute decompensated heart failure. European Heart Journal 201435 3434-3441. (doi:10.1093/ eurheartj/ehu314)

26 Giuliani I, Rieunier F, Larue C, Delagneau JF, Granier C, Pau B, Ferriere M, Saussine M, Cristol JP, Dupuy AM et al. Assay for measurement of intact B-type natriuretic peptide prohormone in blood. Clinical Chemistry 200652 1054-1061. (doi:10.1373/clinchem. 2005.061770)

27 Macheret F, Boerrigter G, McKie P, Costello-Boerrigter L, Lahr B, Heublein D, Sandberg S, Ikeda Y, Cataliotti A, Bailey K et al. Pro-B-type natriuretic peptide(1-108) circulates in the general community: plasma determinants and detection of left ventricular dysfunction. Journal of the American College of Cardiology 201157 1386-1395. (doi:10.1016/j.jacc.2011.01.005)

28 McMurray JJ, Packer M, Desai AS, Gong J, Lefkowitz MP, Rizkala AR, Rouleau JL, Shi VC, Solomon SD, Swedberg K et al. Angiotensin-neprilysin inhibition versus enalapril in heart failure. New England Journal of Medicine 2014371 993-1004. (doi:10.1056/ NEJMoa1409077)

29 Young JB, Dunlap ME, Pfeffer MA, Probstfield JL, Cohen-Solal A Dietz R, Granger CB, Hradec J, Kuch J, McKelvie RS et al. Mortality and morbidity reduction with Candesartan in patients with chronic heart failure and left ventricular systolic dysfunction: results of the CHARM low-left ventricular ejection fraction trials. Circulation 2004110 2618-2626. (doi:10.1161/01.CIR.0000146819.43235.A9)

30 Cohn JN \& Tognoni G. A randomized trial of the angiotensin-receptor blocker valsartan in chronic heart failure. New England Journal of Medicine 2001345 1667-1675. (doi:10.1056/NEJMoa010713)

31 Bohm M, Pogue J, Kindermann I, Poss J, Koon T \& Yusuf S. Effect of comorbidities on outcomes and angiotensin converting enzyme inhibitor effects in patients with predominantly left ventricular dysfunction and heart failure. European Journal of Heart Failure 201416 325-333. (doi:10.1002/ejhf.23)

32 Pouleur H, Rousseau MF, van Eyll C, Stoleru L, Hayashida W, Udelson JA, Dolan N, Kinan D, Gallagher P, Ahn S et al. Effects of longterm enalapril therapy on left ventricular diastolic properties in patients with depressed ejection fraction. SOLVD Investigators. Circulation 199388 481-491. (doi:10.1161/01.CIR.88.2.481)

33 Samocha-Bonet D, Dixit VD, Kahn CR, Leibel RL, Lin X, Nieuwdorp M, Pietilainen KH, Rabasa-Lhoret R, Roden M, Scherer PE et al. Metabolically healthy and unhealthy obese - the 2013 Stock Conference report. Obesity Reviews 201415 697-708. (doi:10.1111/obr.12199)

34 Alberti KG, Eckel RH, Grundy SM, Zimmet PZ, Cleeman JI, Donato KA Fruchart JC, James WP, Loria CM \& Smith SC Jr. Harmonizing the metabolic syndrome: a joint interim statement of the International Diabetes Federation Task Force on Epidemiology and Prevention; National Heart, Lung, and Blood Institute; American Heart Association; World Heart Federation; International Atherosclerosis Society; and International Association for the Study of Obesity. Circulation 2009120 1640-1645. (doi:10.1161/CIRCULATIONAHA.109.192644)

35 Stefan N, Kantartzis K, Machann J, Schick F, Thamer C, Rittig K, Balletshofer B, Machicao F, Fritsche A \& Haring HU. Identification and characterization of metabolically benign obesity in humans. Archives of Internal Medicine 2008168 1609-1616. (doi:10.1001/archinte.168. 15.1609)

36 Morkedal B, Vatten LJ, Romundstad PR, Laugsand LE \& Janszky I. Risk of myocardial infarction and heart failure among metabolically healthy but obese individuals: HUNT (Nord-Trondelag Health Study), Norway. Journal of the American College of Cardiology 201463 1071-1078. (doi:10.1016/j.jacc.2013.11.035)

37 Wirth J, Buijsse B, di GR, Fritsche A, Hense HW, Westphal S, Isermann B, Boeing $\mathrm{H} \&$ Weikert C. Relationship between N-terminal pro-brain natriuretic peptide, obesity and the risk of heart failure in middle-aged german adults. PLOS ONE 20149 e113710. (doi:10.1371/ journal.pone.0113710)

38 Zastrow A, Wolf J, Giannitsis E, Katus H, Herzog W, Friederich HC \& Mussler C. Elevated myocardial enzymes and natriuretic peptides in anorexia nervosa: prototypic condition for the pathophysiology of cachexia? Cardiology 2011118 256-259. (doi:10.1159/000329512)

39 Gloy VL, Briel M, Bhatt DL, Kashyap SR, Schauer PR, Mingrone G, Bucher HC \& Nordmann AJ. Bariatric surgery versus non-surgical treatment for obesity: a systematic review and meta-analysis of randomised controlled trials. BMJ $20133 \mathbf{3 4 7}$ f5934. (doi:10.1136/ bmj.f5934)

40 Wikiel KJ, McCloskey CA \& Ramanathan RC. Bariatric surgery: a safe and effective conduit to cardiac transplantation. Surgery for Obesity and Related Diseases 201410 479-484. (doi:10.1016/j.soard.2013.11.002)

41 Johnson BL, Blackhurst DW, Latham BB, Cull DL, Bour ES, Oliver TL, Williams B, Taylor SM \& Scott JD. Bariatric surgery is associated with a reduction in major macrovascular and microvascular complications in moderately to severely obese patients with type 2 diabetes mellitus. Journal of the American College of Surgeons 2013216 545-556. (doi:10.1016/j.jamcollsurg.2012.12.019)

42 Chaudhry UI, Kanji A, Sai-Sudhakar CB, Higgins RS \& Needleman BJ. Laparoscopic sleeve gastrectomy in morbidly obese patients with endstage heart failure and left ventricular assist device: medium-term results. Surgery for Obesity and Related Diseases 201511 88-93. (doi:10.1016/j.soard.2014.04.003)

43 Miranda WR, Batsis JA, Sarr MG, Collazo-Clavell ML, Clark MM, Somers VK \& Lopez-Jimenez F. Impact of bariatric surgery on quality of life, functional capacity, and symptoms in patients with heart failure. Obesity Surgery 201323 1011-1015. (doi:10.1007/s11695-0130953-8)

44 Alpert MA, Nusair MB, Mukerji R, Omran J, Mehra A, Ardhanari S, Kumar SA \& Terry BE. Effect of weight loss on ventricular repolarization in normotensive severely obese patients with and without heart failure. American Journal of the Medical Sciences 2015349 17-23. (doi:10.1097/MAJ.0000000000000342)

45 Vest AR \& Young JB. Should we target obesity in advanced heart failure? Current Treatment Options in Cardiovascular Medicine 201416 284. (doi:10.1007/s11936-013-0284-z)

46 Abrahamsson N, Engstrom BE, Sundbom M \& Karlsson FA. Gastric bypass surgery elevates NT-ProBNP levels. Obesity Surgery 201323 1421-1426. (doi:10.1007/s11695-013-0889-z)

47 Arjamaa $\mathrm{O} \&$ Nikinmaa $\mathrm{M}$. Hypoxia regulates the natriuretic peptide system. International Journal of Physiology, Pathophysiology and Pharmacology 20113 191-201.

48 Magga J, Marttila M, Mäntymaa P, Vuolteenaho O \& Ruskoaho H. Brain natriuretic peptide in plasma, atria, and ventricles of 
vasopressin- and phenylephrine-infused conscious rats. Endocrinology $19941342505-2515$

49 Tateishi J, Masutani M, Ohyanagi M \& Iwasaki T. Transient increase in plasma brain (B-type) natriuretic peptide after percutaneous transluminal coronary angioplasty. Clinical Cardiology 200023 776-780. (doi:10.1002/clc.4960231016)

50 Richards AM, Nicholls MG, Espiner EA, Lainchbury JG, Troughton RW, Elliott J, Frampton C, Turner J, Crozier IG \& Yandle TG. B-type natriuretic peptides and ejection fraction for prognosis after myocardial infarction. Circulation $2003 \mathbf{1 0 7}$ 2786-2792. (doi:10.1161/01.CIR.0000070953.76250.B9)

51 Kragelund C, Gronning B, Kober L, Hildebrandt P \& Steffensen R. $\mathrm{N}$-terminnal pro-B-type natriuretic peptide and long-term mortality in stable coronary heart disease. New England Journal of Medicine 2005 352 666-675. (doi:10.1056/NEJMoa042330)

52 Mishra RK, Beatty AL, Jaganath R, Regan M, Wu AH \& Whooley MA. B-type natriuretic peptides for the prediction of cardiovascular events in patients with stable coronary heart disease: the Heart and Soul Study. Journal of the American Heart Association $20143 \mathrm{e}$ e00907. (doi:10.1161/JAHA.114.000907)

53 Fradley MG, Larson MG, Cheng S, McCabe E, Coglianese E, Shah RV, Levy D, Vasan RS \& Wang TJ. Reference limits for N-terminal-pro-Btype natriuretic peptide in healthy individuals (from the Framingham Heart Study). American Journal of Cardiology 2011108 1341-1345. (doi:10.1016/j.amjcard.2011.06.057)

54 Nordenskjold AM, Ahlstrom H, Eggers KM, Frobert O, Venge P \& Lindahl B. Short- and long-term individual variation in NT-proBNP levels in patients with stable coronary artery disease. Clinica Chimica Acta 2013422 15-20. (doi:10.1016/j.cca.2013.03.025)

55 Galvani M, Ottani F, Oltrona L, Ardissino D, Gensini GF, Maggioni AP, Mannucci PM, Mininni N, Prando MD, Tubaro M et al. N-terminal probrain natriuretic peptide on admission has prognostic value across the whole spectrum of acute coronary syndromes. Circulation 2004110 128-134. (doi:10.1161/01.CIR.0000134480.06723.D8)

56 Bassan R, Potsch A, Maisel A, Tura B, Villacorta H, Nogueira MV, Campos A, Gamarski R, Masetto AC \& Moutinho MA. B-type natriuretic peptide: a novel early blood marker of acute myocardial infarction in patients with chest pain and no ST-segment elevation. European Heart Journal 200526 234-240. (doi:10.1093/eurheartj/ehi033)

57 Bassan R, Tura BR \& Maisel AS. B-type natriuretic peptide: a strong predictor of early and late mortality in patients with acute chest pain without ST-segment elevation in the emergency department. Coronary Artery Disease 200920 143-149. (doi:10.1097/MCA. Ob013e3283292ac6)

58 Melki D, Lind S, Agewall S \& Jernberg T. Prognostic value of combining high sensitive troponin $\mathrm{T}$ and $\mathrm{N}$-terminal pro B-type natriuretic peptide in chest pain patients with no persistent ST-elevation. Clinica Chimica Acta 2012413 933-937. (doi:10.1016/j.cca.2012.02.008)

59 Foote RS, Pearlman JD, Siegel AH \& Yeo KT. Detection of exerciseinduced ischemia by changes in B-type natriuretic peptides. Journal of the American College of Cardiology 200444 1980-1987. (doi:10.1016/ j.jacc.2004.08.045)

60 Weber M, Bazzino O, NavarroEstrada JL, Fuselli JJ, Botto F, Perezde AD, Mollmann H, Nef HN, Elsasser A \& Hamm CW. N-terminal B-type natriuretic peptide assessment provides incremental prognostic information in patients with acute coronary syndromes and normal troponin T values upon admission. Journal of the American College of Cardiology 200851 1188-1195. (doi:10.1016/j.jacc.2007.11.054)

61 Truong QA, Bayley J, Hoffmann U, Bamberg F, Schlett CL, Nagurney JT, Koenig W \& Januzzi JL. Multi-marker strategy of natriuretic peptide with either conventional or high-sensitivity troponin-T for acute coronary syndrome diagnosis in emergency department patients with chest pain: from the "Rule Out Myocardial Infarction using Computer Assisted Tomography" (ROMICAT) trial. American Heart Journal 2012163 972-979. (doi:10.1016/ j.ahj.2012.03.010)
62 Garcia-Alvarez A, Regueiro A, Hernandez J, Kasa G, Sitges M, Bosch X $\&$ Heras M. Additional value of B-type natriuretic peptide on discrimination of patients at risk for mortality after a non-ST-segment elevation acute coronary syndrome. European Heart Journal. Acute Cardiovascular Care 20143 132-140. (doi:10.1177/ 2048872614520753)

63 Amsterdam EA, Wenger NK, Brindis RG, Casey DE Jr, Ganiats TG, Holmes DR Jr, Jaffe AS, Jneid H, Kelly RF, Kontos MC et al. AHA/ACC guideline for the management of patients with non-ST-elevation acute coronary syndromes: a report of the American College of Cardiology/American Heart Association TASK Force on Practice Guidelines. Journal of the American College of Cardiology 201464 e139-e228. (doi:10.1016/j.jacc.2014.09.017)

64 Bjorklund E, Jernberg T, Johanson P, Venge P, Dellborg M, Wallentin L \& Lindahl B. Admission N-terminal pro-brain natriuretic peptide and its interaction with admission troponin $\mathrm{T}$ and ST segment resolution for early risk stratification in ST elevation myocardial infarction. Heart 200692 735-740. (doi:10.1136/hrt.2005.072975)

65 Scirica BM, Kadakia MB, de Lemos JA, Roe MT, Morrow DA, Li S, Wiviott SD \& Kontos MC. Association between natriuretic peptides and mortality among patients admitted with myocardial infarction: a report from the ACTION Registry(R)-GWTG. Clinical Chemistry 2013 59 1205-1214. (doi:10.1373/clinchem.2012.198556)

66 Schellings DA, Adiyaman A, Giannitsis E, Hamm C, Suryapranata H, ten Berg JM, Hoorntje JC \& Van't Hof AW. Early discharge after primary percutaneous coronary intervention: the added value of N-terminal pro-brain natriuretic peptide to the Zwolle Risk Score Journal of the American Heart Association 20143 e001089. (doi:10.1161/ JAHA.114.001089)

67 John SW, Krege JH, Oliver PM, Hagaman JR, Hodgin JB, Pang SC, Flynn TG \& Smithies O. Genetic decreases in atrial natriuretic peptide and salt-sensitive hypertension. Science 1995267 679-681. (doi:10.1126/science.7839143)

68 Newton-Cheh C, Johnson T, Gateva V, Tobin MD, Bochud M, Coin L, Najjar SS, Zhao JH, Heath SC, Eyheramendy S et al. Genome-wide association study identifies eight loci associated with blood pressure. Nature Genetics 200941 666-676. (doi:10.1038/ng.361)

69 Newton-Cheh C, Larson MG, Vasan RS, Levy D, Bloch KD, Surti A, Guiducci C, Kathiresan S, Benjamin EJ, Struck J et al. Association of common variants in NPPA and NPPB with circulating natriuretic peptides and blood pressure. Nature Genetics 200941 348-353. (doi:10.1038/ng.328)

70 Macheret F, Heublein D, Costello-Boerrigter LC, Boerrigter G, McKie P, Bellavia D, Mangiafico S, Ikeda Y, Bailey K, Scott CG et al. Human hypertension is characterized by a lack of activation of the antihypertensive cardiac hormones ANP and BNP. Journal of the American College of Cardiology 201260 1558-1565. (doi:10.1016/j.jacc.2012.05.049)

71 de Bold MK, Sheffield WP, Martinuk A, Bhakta V, Eltringham-Smith L $\&$ de Bold AJ. Characterization of a long-acting recombinant human serum albumin-atrial natriuretic factor (ANF) expressed in Pichia pastoris. Regulatory Peptides 2012175 7-10. (doi:10.1016/j.regpep. 2012.01.005)

72 Cataliotti A, Schirger JA, Martin FL, Chen HH, McKie PM, Boerrigter G, Costello-Boerrigter LC, Harty G, Heublein DM, Sandberg SM et al. Oral human brain natriuretic peptide activates cyclic guanosine $3^{\prime}, 5^{\prime}$-monophosphate and decreases mean arterial pressure. Circulation 2005112 836-840. (doi:10.1161/CIRCULATIONAHA.105.538520)

73 Cataliotti A, Costello-Boerrigter LC, Chen HH, Textor SC \& Burnett JC Jr. Sustained blood pressure-lowering actions of subcutaneous B-type natriuretic peptide (nesiritide) in a patient with uncontrolled hypertension. Mayo Clinic Proceedings 201287 413-415. (doi:10.1016/j.mayocp.2012.02.003)

74 Das SR, Drazner MH, Dries DL, Vega GL, Stanek HG, Abdullah SM, Canham RM, Chung AK, Leonard D, Wians FH Jr et al. Impact of body mass and body composition on circulating levels of natriuretic 
peptides: results from the Dallas Heart Study. Circulation 2005112 2163-2168. (doi:10.1161/CIRCULATIONAHA.105.555573)

75 Olsen MH, Hansen TW, Christensen MK, Gustafsson F, Rasmussen S, Wachtell K, Borch-Johnsen K, Ibsen H, Jorgensen T \& Hildebrandt P. $\mathrm{N}$-terminal pro brain natriuretic peptide is inversely related to metabolic cardiovascular risk factors and the metabolic syndrome. Hypertension 200546 660-666. (doi:10.1161/01.HYP.0000179575. 13739.72)

76 Khan AM, Cheng S, Magnusson M, Larson MG, Newton-Cheh C, McCabe EL, Coviello AD, Florez JC, Fox CS, Levy D et al. Cardiac natriuretic peptides, obesity, and insulin resistance: evidence from two community-based studies. Journal of Clinical Endocrinology and Metabolism 201196 3242-3249. (doi:10.1210/jc.2011-1182)

77 Sugisawa T, Kishimoto I, Kokubo Y, Makino H, Miyamoto Y \& Yoshimasa Y. Association of plasma B-type natriuretic peptide levels with obesity in a general urban Japanese population: the Suita Study. Endocrine Journal 201057 727-733. (doi:10.1507/endocri.K10E-067)

78 Cannone V, Cefalu' AB, Noto D, Scott CG, Bailey KR, Cavera G, Pagano M, Sapienza M, Averna MR \& Burnett JC Jr. The atrial natriuretic peptide genetic variant rs5068 is associated with a favorable cardiometabolic phenotype in a Mediterranean population. Diabetes Care 201336 2850-2856. (doi:10.2337/dc12-2337)

79 Stavrakis S, Pakala A, Thomas J, Chaudhry MA \& Thadani U. Obesity, brain natriuretic peptide levels and mortality in patients hospitalized with heart failure and preserved left ventricular systolic function. American Journal of the Medical Sciences 2013345 211-217. (doi:10.1097/MAJ.0b013e318271c012)

80 Kenny AJ, Bourne A \& Ingram J. Hydrolysis of human and pig brain natriuretic peptides, urodilatin, C-type natriuretic peptide and some C-receptor ligands by endopeptidase-24.11. Biochemical journal 1993 291 83-88.

81 Maack T, Suzuki M, Almeida FA, Nussenzveig D, Scarborough RM, McEnroe GA \& Lewicki JA. Physiological role of silent receptors of atrial natriuretic factor. Science 1987238 675-678. (doi:10.1126/ science.2823385)

82 Sarzani R, Dessì-Fulgheri P, Paci VM, Espinosa E \& Rappelli A. Expression of natriuretic peptide receptors in human adipose and other tissues. Journal of Endocrinological Investigation 199619 581-585. (doi:10.1007/BF03349021)

83 Pivovarova O, Gogebakan O, Kloting N, Sparwasser A, Weickert MO, Haddad I, Nikiforova VJ, Bergmann A, Kruse M, Seltmann AC et al. Insulin up-regulates natriuretic peptide clearance receptor expression in the subcutaneous fat depot in obese subjects: a missing link between CVD risk and obesity? Journal of Clinical Endocrinology and Metabolism 201297 E731-E739. (doi:10.1210/jc.2011-2839)

84 Nakatsuji H, Maeda N, Hibuse T, Hiuge A, Hirata A, Kuroda Y, Kishida K, Kihara S, Funahashi T \& Shimomura I. Reciprocal regulation of natriuretic peptide receptors by insulin in adipose cells. Biochemical and Biophysical Research Communications 2010392 100-105. (doi:10.1016/j.bbrc.2010.01.008)

85 Dessi-Fulgheri P, Sarzani R, Tamburrini P, Moraca A, Espinosa E, Cola G, Giantomassi L \& Rappelli A. Plasma atrial natriuretic peptide and natriuretic peptide receptor gene expression in adipose tissue of normotensive and hypertensive obese patients. Journal of Hypertension 199715 1695-1699. (doi:10.1097/00004872-199715120-00074)

86 Standeven KF, Hess K, Carter AM, Rice GI, Cordell PA, Balmforth AJ, Lu B, Scott DJ, Turner AJ, Hooper NM et al. Neprilysin, obesity and the metabolic syndrome. International Journal of Obesity 201135 1031-1040. (doi:10.1038/ijo.2010.227)

87 Jung DY, Ha H, Lee E, Hu X, Tran DA, Tsitsilianos N, Tsitsilianos AV, Garvin AC, Hsu K, Binny MH et al. BNP is a novel cardiomyokine that regulates hepatic inuslin action in diet induced obese mice. Diabetes (Supplement 1) 201463 37-OR.

88 Stamler R, Stamler J, Riedlinger WF, Algera G \& Roberts RH. Weight and blood pressure. Findings in hypertension screening of 1 million
Americans. Journal of the American Medical Association $1978 \mathbf{2 4 0}$ 1607-1610. (doi:10.1001/jama.1978.03290150053024)

89 Aneja A, El-Atat F, McFarlane SI \& Sowers JR. Hypertension and obesity. Recent Progress in Hormone Research 200459 169-205. (doi:10.1210/rp.59.1.169)

90 Jordan J \& Engeli S. Obesity, hypertension, and cardiovascular health: is there anything poor Cassandra tries to tell us? Journal of Hypertension 201230 1103-1105. (doi:10.1097/HJH.0b013e3283542da0)

91 Clinkingbeard C, Sessions C \& Shenker Y. The physiological role of atrial natriuretic hormone in the regulation of aldosterone and salt and water metabolism. Journal of Clinical Endocrinology and Metabolism 199070 582-589. (doi:10.1210/jcem-70-3-582)

92 Bruun NE, Dige-Pedersen H \& Skott P. Normal responses of atrial natriuretic factor and renal tubular function to sodium loading in hypertension-prone humans. Blood Pressure 20009 206-213. (doi:10.1080/080370500439092)

93 Uehlinger DE, Zaman T, Weidmann P, Shaw S \& Gn:adinger MP. Pressure dependence of atrial natriuretic peptide during norepinephrine infusion in humans. Hypertension 198710 249-253. (doi:10.1161/01.HYP.10.3.249)

94 Park BM, Oh YB, Gao S, Cha SA, Kang KP \& Kim SH. Angiotensin III, stimulates high stretch-induced ANP secretion via angiotensin type 2 receptor. Peptides 201342 131-137. (doi:10.1016/j.peptides. 2013.01.018)

95 Asferg CL, Nielsen SJ, Andersen UB, Linneberg A, Moller DV, Hedley PL, Christiansen M, Goetze JP, Esler M \& Jeppesen JL. Relative atrial natriuretic peptide deficiency and inadequate renin and angiotensin II suppression in obese hypertensive men. Hypertension 201362 147-153. (doi:10.1161/HYPERTENSIONAHA.111.00791)

96 Rubattu S, Bigatti G, Evangelista A, Lanzani C, Stanzione R, Zagato L, Manunta P, Marchitti S, Venturelli V, Bianchi G et al. Association of atrial natriuretic peptide and type a natriuretic peptide receptor gene polymorphisms with left ventricular mass in human essential hypertension. Journal of the American College of Cardiology 200648 499-505. (doi:10.1016/j.jacc.2005.12.081)

97 Rubattu S, Sciarretta S, Ciavarella GM, Venturelli V, De Paolis P, Tocci G, De Biase L, Ferrucci A \& Volpe M. Reduced levels of $\mathrm{N}$-terminal-proatrial natriuretic peptide in hypertensive patients with metabolic syndrome and their relationship with left ventricular mass. Journal of Hypertension 200725 833-839. (doi:10.1097/HJH. 0b013e32803cae3c)

98 Sengenes C, Berlan M, De G I, Lafontan M \& Galitzky J. Natriuretic peptides: a new lipolytic pathway in human adipocytes. FASEB Journal 200014 1345-1351. (doi:10.1096/fj.14.10.1345)

99 Galitzky J, Sengenes C, Thalamas C, Marques MA, Senard JM, Lafontan M \& Berlan M. The lipid-mobilizing effect of atrial natriuretic peptide is unrelated to sympathetic nervous system activation or obesity in young men. Journal of Lipid Research $2001 \mathbf{4 2} 536-544$

100 Schlueter N, de Sterke A, Willmes DM, Spranger J, Jordan J \& Birkenfeld AL. Metabolic actions of natriuretic peptides and therapeutic potential in the metabolic syndrome. Pharmacology \& Therapeutics 2014144 12-27. (doi:10.1016/j.pharmthera.2014.04.007)

101 Birkenfeld AL, Adams F, Schroeder C, Engeli S \& Jordan J. Metabolic actions could confound advantageous effects of combined angiotensin II receptor and neprilysin inhibition. Hypertension 201157 e4-e5. (doi:10.1161/HYPERTENSIONAHA.110.165159)

102 Birkenfeld AL, Boschmann M, Moro C, Adams F, Heusser K, Franke G, Berlan M, Luft FC, Lafontan M \& Jordan J. Lipid mobilization with physiological atrial natriuretic peptide concentrations in humans. Journal of Clinical Endocrinology and Metabolism 200590 3622-3628. (doi:10.1210/jc.2004-1953)

103 Moro C, Galitzky J, Sengenes C, Crampes F, Lafontan M \& Berlan M. Functional and pharmacological characterization of the natriuretic peptide-dependent lipolytic pathway in human fat cells. Journal of Pharmacology and Experimental Therapeutics 2004308 984-992. (doi:10.1124/jpet.103.060913) 
104 Birkenfeld AL, Boschmann M, Engeli S, Moro C, Arafat AM, Luft FC \& Jordan J. Atrial natriuretic peptide and adiponectin interactions in man. PLOS ONE 20127 e43238. (doi:10.1371/journal.pone.0043238)

105 Kistorp C, Faber J, Galatius S, Gustafsson F, Frystyk J, Flyvbjerg A \& Hildebrandt P. Plasma adiponectin, body mass index, and mortality in patients with chronic heart failure. Circulation 2005112 1756-1762. (doi:10.1161/CIRCULATIONAHA.104.530972)

106 Azizi Ghanbari A, Dorr R, Spitzer S, Stumpf J, Britz A, Amann-Zalan I, Lodwig V, Ulm B, Schnell O \& Lohmann T. Adiponectin in coronary heart disease and newly diagnosed impaired glucose tolerance. Diabetes \& Vascular Disease Research 201310 452-458. (doi:10.1177/ 1479164113490179)

107 Bordicchia M, Liu D, Amri EZ, Ailhaud G, Dessi-Fulgheri P, Zhang C, Takahashi N, Sarzani R \& Collins S. Cardiac natriuretic peptides act via p38 MAPK to induce the brown fat thermogenic program in mouse and human adipocytes. Journal of Clinical Investigation 2012122 1022-1036. (doi:10.1172/JCI59701)

108 Collins S. A heart-adipose tissue connection in the regulation of energy metabolism. Nature Reviews. Endocrinology 201410 157-163. (doi:10.1038/nrendo.2013.234)

109 Birkenfeld AL, Boschmann M, Moro C, Adams F, Heusser K, Tank J, Diedrich A, Schroeder C, Franke G, Berlan M et al. $\beta$-adrenergic and atrial natriuretic peptide interactions on human cardiovascular and metabolic regulation. Journal of Clinical Endocrinology and Metabolism 200691 5069-5075. (doi:10.1210/jc.2006-1084)

110 Birkenfeld AL, Budziarek P, Boschmann M, Moro C, Adams F, Franke G, Berlan M, Marques MA, Sweep FC, Luft FC et al. Atrial natriuretic peptide induces postprandial lipid oxidation in humans. Diabetes 200857 3199-3204. (doi:10.2337/db08-0649)

111 Miyashita K, Itoh H, Tsujimoto H, Tamura N, Fukunaga Y, Sone M, Yamahara K, Taura D, Inuzuka M, Sonoyama T et al. Natriuretic peptides/cGMP/cGMP-dependent protein kinase cascades promote muscle mitochondrial biogenesis and prevent obesity. Diabetes 2009 58 2880-2892. (doi:10.2337/db09-0393)

112 Engeli S, Birkenfeld AL, Badin PM, Bourlier V, Louche K, Viguerie N, Thalamas C, Montastier E, Larrouy D, Harant I et al. Natriuretic peptides enhance the oxidative capacity of human skeletal muscle. Journal of Clinical Investigation 2012122 4675-4679. (doi:10.1172/JCI64526)

113 Birkenfeld AL \& Shulman GI. Nonalcoholic fatty liver disease, hepatic insulin resistance, and type 2 diabetes. Hepatology 201459 713-723. (doi:10.1002/hep.26672)

114 Mitsuishi M, Miyashita K \& Itoh H. cGMP rescues mitochondrial dysfunction induced by glucose and insulin in myocytes. Biochemical and Biophysical Research Communications 2008367 840-845. (doi:10.1016/j.bbrc.2008.01.017)

115 Nisoli E, Clementi E, Paolucci C, Cozzi V, Tonello C, Sciorati C, Bracale R, Valerio A, Francolini M, Moncada S et al. Mitochondrial biogenesis in mammals: the role of endogenous nitric oxide. Science 2003299 896-899. (doi:10.1126/science.1079368)

116 Lee HY, Choi CS, Birkenfeld AL, Alves TC, Jornayvaz FR, Jurczak MJ, Zhang D, Woo DK, Shadel GS, Ladiges W et al. Targeted expression of catalase to mitochondria prevents age-associated reductions in mitochondrial function and insulin resistance. Cell Metabolism 2010 12 668-674. (doi:10.1016/j.cmet.2010.11.004)

117 Birkenfeld AL, Lee HY, Guebre-Egziabher F, Alves TC, Jurczak MJ, Jornayvaz FR, Zhang D, Hsiao JJ, Martin-Montalvo A, FischerRosinsky A et al. Deletion of the mammalian INDY homolog mimics aspects of dietary restriction and protects against adiposity and insulin resistance in mice. Cell Metabolism 201114 184-195. (doi:10.1016/ j.cmet.2011.06.009)

118 Perry RJ, Kim T, Zhang XM, Lee HY, Pesta D, Popov VB, Zhang D, Rahimi Y, Jurczak MJ, Cline GW et al. Reversal of hypertriglyceridemia, fatty liver disease, and insulin resistance by a liver-targeted mitochondrial uncoupler. Cell Metabolism 201318 740-748. (doi:10.1016/j.cmet.2013.10.004)
119 Heinisch BB, Vila G, Resl M, Riedl M, Dieplinger B, Mueller T, Luger A, Pacini G \& Clodi M. B-type natriuretic peptide (BNP) affects the initial response to intravenous glucose: a randomised placebo-controlled cross-over study in healthy men. Diabetologia 201255 1400-1405. (doi:10.1007/s00125-011-2392-1)

120 Neeland IJ, Winders BR, Ayers CR, Das SR, Chang AY, Berry JD, Khera A, McGuire DK, Vega GL, de Lemos JA et al. Higher natriuretic peptide levels associate with a favorable adipose tissue distribution profile. Journal of the American College of Cardiology 201362 752-760. (doi:10.1016/j.jacc.2013.03.038)

121 Everett BM, Cook NR, Chasman DI, Magnone MC, Bobadilla M, Rifai N, Ridker PM \& Pradhan AD. Prospective evaluation of B-type natriuretic peptide concentrations and the risk of type 2 diabetes in women. Clinical Chemistry 201359 557-565. (doi:10.1373/clinchem. 2012.194167)

122 Pfister R, Sharp S, Luben R, Welsh P, Barroso I, Salomaa V, Meirhaeghe A, Khaw KT, Sattar N, Langenberg C et al. Mendelian randomization study of B-type natriuretic peptide and type 2 diabetes: evidence of causal association from population studies. PLoS Medicine 20118 e1001112. (doi:10.1371/journal.pmed.1001112)

123 Magnusson M, Jujic A, Hedblad B, Engstrom G, Persson M, Struck J, Morgenthaler NG, Nilsson P, Newton-Cheh C, Wang TJ et al. Low plasma level of atrial natriuretic peptide predicts development of diabetes: the prospective Malmo Diet and Cancer study. Journal of Clinical Endocrinology and Metabolism 201297 638-645. (doi:10.1210/jc.2011-2425)

124 Martin J, Bergeron S, Pibarot P, Bastien M, Biertho L, Lescelleur O, Bertrand F, Simard S \& Poirier P. Impact of bariatric surgery on N-terminal fragment of the prohormone brain natriuretic peptide and left ventricular diastolic function. Canadian Journal of Cardiology 2013 29 969-975. (doi:10.1016/j.cjca.2012.11.010)

125 Bertoni AG, Wagenknecht LE, Kitzman DW, Marcovina SM, Rushing JT \& Espeland MA. Brain natriuretic peptide subgroup of the look ARG. impact of the look ahead intervention on NT-pro brain natriuretic peptide in overweight and obese adults with diabetes. Obesity 201220 1511-1518. (doi:10.1038/oby.2011.296)

126 Chen-Tournoux A, Khan AM, Baggish AL, Castro VM, Semigran MJ, McCabe EL, Moukarbel G, Reingold J, Durrani S, Lewis GD et al. Effect of weight loss after weight loss surgery on plasma N-terminal pro-Btype natriuretic peptide levels. American Journal of Cardiology 2010106 1450-1455. (doi:10.1016/j.amjcard.2010.06.076)

127 Haufe S, Haas V, Utz W, Birkenfeld AL, Jeran S, Bohnke J, Mahler A, Luft FC, Schulz-Menger J, Boschmann $\mathrm{M}$ et al. Long-lasting improvements in liver fat and metabolism despite body weight regain after dietary weight loss. Diabetes Care 201336 3786-3792. (doi:10.2337/dc13-0102)

128 Kim M, Platt MJ, Shibasaki T, Quaggin SE, Backx PH, Seino S, Simpson JA \& Drucker DJ. GLP-1 receptor activation and Epac2 link atrial natriuretic peptide secretion to control of blood pressure. Nature Medicine 201319 567-575. (doi:10.1038/nm.3128)

129 Skov J, Holst JJ, Gotze JP, Frokiaer J \& Christiansen JS. Glucagon-like peptide-1: effect on pro-atrial natriuretic peptide in healthy males. Endocrine Connections 20143 11-16. (doi:10.1530/EC-13-0087)

130 Lovshin JA, Barnie A, Dealmeida A, Logan A, Zinman B \& Drucker DJ. Liraglutide promotes natriuresis but does not increase circulating levels of atrial natriuretic peptide in hypertensive subjects with type 2 diabetes. Diabetes Care 201538 132-139. (doi:10.2337/dc14-1958)

131 Li CJ, Yu Q, Yu P, Yu TL, Zhang QM, Lu S \& Yu DM. Changes in liraglutide-induced body composition are related to modifications in plasma cardiac natriuretic peptides levels in obese type 2 diabetic patients. Cardiovascular Diabetology 201413 36. (doi:10.1186/1475-2840-13-36)

132 Haufe S, Kaminski J, Utz W, Haas V, Mahler A, Daniels MA, Birkenfeld AL, Lichtinghagen R, Luft FC \& Schulz-Menger J. Differential response of the natriuretic peptide system to weight loss and exercise in overweight or obese patients. Journal of Hypertension 2015.

133 Roberts E, Ludman AJ, Dworzynski K, Al-Mohammad A, Cowie MR, McMurray JJ \& Mant J. The diagnostic accuracy of the natriuretic 
peptides in heart failure: systematic review and diagnostic metaanalysis in the acute care setting. BMJ $2015350 \mathrm{~h} 910$.

134 Masson S, Latini R, Anand IS, Vago T, Angelici L, Barlera S, Missov ED, Clerico A, Tognoni G \& Cohn JN. Direct comparison of B-type natriuretic peptide (BNP) and amino-terminal proBNP in a large population of patients with chronic and symptomatic heart failure: the Valsartan Heart Failure (Val-HeFT) data. Clinical Chemistry 200652 $1528-1538$.

135 Maisel AS, Nakao K, Ponikowski P, Peacock WF, Yoshimura M, Suzuki T, Tsutamoto T, Filippatos GS, Saito Y, Seino Y et al. JapaneseWestern consensus meeting on biomarkers. International Heart Journal $201152253-265$

Received in final form 8 May 2015

Accepted 21 May 2015
This work is licensed under a Creative Commons Attribution-NonCommercial 4.0 International License. 